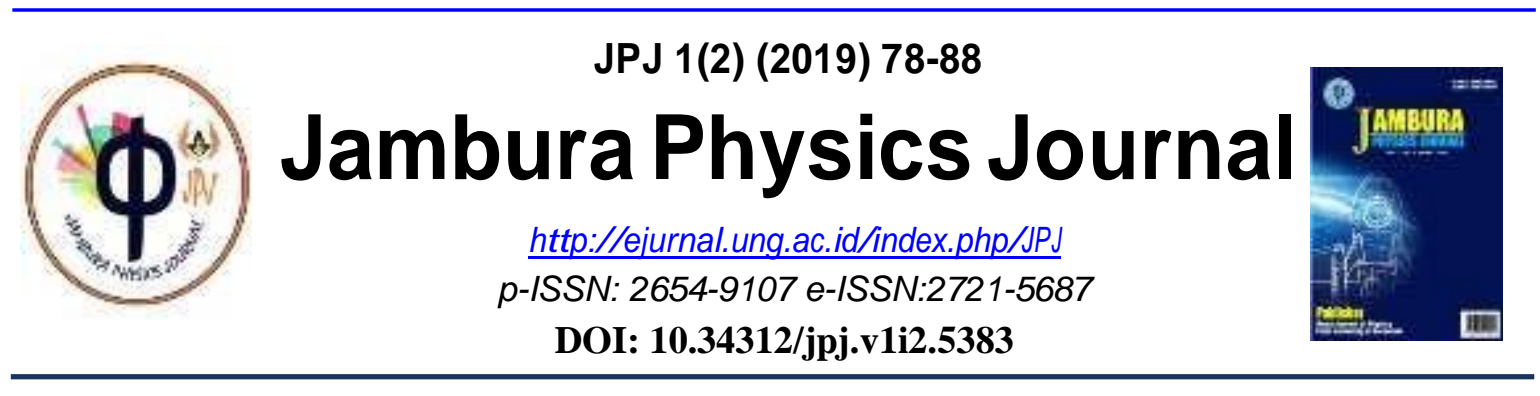

\title{
PENGEMBANGAN PERANGKAT PEMBELAJARAN INKUIRI TERBIMBING BERBASIS BUDAYA LOKAL TERHADAP HASIL BELAJAR PADA MATERI ENERGI DALAM SISTEM KEHIDUPAN
}

\author{
Montu F. ${ }^{1}$, Abdjul T. ${ }^{*}$ \\ ${ }^{1}$ Jurusan Fisika Universitas Negeri Gorontalo, Gorontalo
}

Accepted: August 30 2019. Approved: October 07 2019. Published: October 302019

\begin{abstract}
The study is aimed is to produce a valid learning device based on local culture, effective, and practical to improve students study outcome on energy concept in a living system. The study is conducted at SMP N 4 Telaga Gorontalo District using the development method of the Four-D device. The findings show that the development device is valid, effective, and practical to use. The device validity is presented from expert' validation result, which stated that the device is ready to use with minor revision. The device is claimed practical based on observation result learning implementation for two weeks which is $97,5 \%, 99,3 \%$, with good criteria, also student questionnaire declared that the device is practical to use with the percentage of $92,14 \%$. The learning device effectiveness is shown with the increasing number of tested study result, which is 0,8 with n-gain high criteria and the result of observation student activity, which is $86,92 \%$ with good criteria.
\end{abstract}

Keywords: Study Outcome, Local Culture, Guided Inquiry

\section{PENDAHULUAN}

Pendidikan memegang peranan penting dalam membentuk generasi penerus bangsa sebagaimana telah tercantum dalam Undang-undang RI nomor 20 tahun 2003 tentang Sistem Pendidikan Nasional, pasal 3 yang menyatakan bahwa pendidikan nasional berfungsi mengembangkan kemampuan dan membentuk watak serta peradaban bangsa yang bermartabat dalam rangka mencerdaskan kehidupan bangsa. Panjaitan, dkk (2014: 22). Hal ini terlihat dengan adanya upaya pemerintah merubah kurikulum pendidikan yang lebih dinamis pada tahun 2013 lalu. Dengan adanya perubahan kurikulum ini pemerintah berharap kualitas

\footnotetext{
*Alamat Korespondensi

E-mail: tirtawaty@ung.ac.id
} 
pendidikan kita akan semakin maju. Permasalahan pembelajaran seperti ini, juga terjadi pada pembelajaran IPA di SMP Negeri 4 Telaga Kabupaten Gorontalo dimana perangkat pembelajaran kegiatan belajar seperti ini tidak sesuai dengan tujuan pembelajaran IPA yaitu BSNP (2006: 3): Mengembangkan pengetahuan dan pemahaman konsep-konsep IPA yang bermanfaat dan dapat diterapkan dalam kehidupan sehari-hari, mengembangkan rasa ingin tahu, sikap positif dan kesadaran tentang adanya hubungan yang saling mempengaruhi antara IPA, lingkungan, teknologi dan masyarakat, mengembangkan keterampilan proses untuk menyelidiki alam sekitar, memecahkan masalah dan membuat keputusan, Meningkatkan 3 kesadaran untuk berperan serta dalam memelihara, menjaga dan melestarikan lingkungan alam. Farida (2015: 2)

Hal ini terlihat ketika melakukan observasi pada tanggal 5 Juni 2018 terhadap guru mata pelajaran IPA Fisika dan beberapa peserta didik mengenai proses pembelajaran yang berlangsung di SMP Negeri 4 Pulubala Kabupaten Gorontalo belum ditemukan perangkat berbasis budaya lokal dan menunjukkan hasil belajar masih rendah. Beberapa faktor yang menyebabkan rendahnya hasil belajar IPA disebabkan karena pengemasan pembelajaran IPA cenderung menciptakan kondisi yang kurang menguntungkan siswa untuk dapat berpikir dan bekerja secara ilmiah dalam membentuk sendiri suatu konsep, peserta didik jarang melakukan eksperimen, pada saat proses pembelajaran guru jarang melibatkan siswa serta model dan metode maupun strategi yang digunakan oleh guru dalam proses pembelajaran masih bersifat umum dan kurang memberikan kesempatan kepada siswa untuk mengembangkan pola pikirnya sesuai dengan kemampuan dan keterampilan masing-masing. Pembelajaran IPA di SMP Negeri 4 Telaga Kabupaten Gorontalo cenderung terkesan bersifat prosedural, monoton dan kurang terbuka bagi partisipasi peserta didik dan membosankan.

Menurut Supardi (2015: 2) yang dimaksud dengan keberhasilan belajar adalah tahap pencapaian actual yang ditampilkan dalam bentuk perilaku yang meliputi aspek kognitif, afektif, maupun psikomotor dan dapat dilihat dalam bentuk kebiasaan, sikap, dan penghargaan.

Menurut Ahmadi (2003: 53) ditinjau dari sudut bahasa Indonesia, kebudayaan berasal dari bahasa Sanskerta "Buddhayah" yaitu bentuk bahasa jamak dari "buddhi" yang berarti budi atau akal. Jadi kebudayaan adalah hasil budi dan akal manusia untuk mencapai kesempurnaan hidup.

Menurut Abdullah (2006: 34) Budaya lokal adalah kebudayaan yang tumbuh dan berkembang serta dimiliki dan diakui oleh masyarakat suku bangsa setempat. Budaya lokal biasanya tumbuh dan berkembang dalam suatu masyarakat suku atau daerah tertentu karena 
warisan turun-temurun yang dilestarikan. Budaya daerah ini akan muncul pada saat penduduk suatu daerah telah memiliki pola pikir dan kehidupan sosial yang sama, sehingga menjadi suatu kebiasaan yang membedakan mereka dengan penduduk-penduduk yang lain. Budaya daerah mulai terlihat berkembang di Indonesia pada zaman kerajaan-kerajaan terdahulu

Pendidikan berbasis budaya lokal membuat peserta didik mampu memahami konsep fisika yang dipelajari dengan didasarkan pada lingkungan konkret di lingkungan sekitar. Pembelajaran berbasis budaya lokal dapat meningkatkan hasil belajar ranah afektif berupa kecintaan terhadap budaya lokal di lingkungan sekitar. Serta pembelajaran yang berbasis budaya lokal juga dapat meningkatkan aktivitas dan hasil belajar siswa.

Salah satu budaya lokal yang ada di Gorontalo yaitu permainan yang sering dilakukan anak-anak yaitu permaianan dari bambu (bunggo) yang mengeluarkan bunyi yang sangat besar ketika di berikan minyak tanah sedikit dan percikan api, bunggo itu akan mengeluarkan bunyi yang membuat para warga Gorontalo akan terbangun pada waktu sahur dan berkumpul bersama memainakan meriam bambu ini (bunggo). Dan juga penggunaan setrika menggunakan batu bara untuk menyetrika pakaian, menyalakan lampu minyak pada tradisi tumbilatohe (3 hari menjelang hari raya idhul fitri). Budaya lokal gorontalo ini berhubungan dengan materi IPA Terpadu pada khususnya dalam bidang fisika pada energi dalam sistem kehidupan . Karna kebiasaan ini pada zaman dahulu orang gorontalo sering memakai alat-alat yang bersifat tradisional untuk menghemat listrik dengan penghematan energi yang mereka gunakan juga masih tradisional. Salah satu contonya mereka menggunakan lampu botol untuk menerangkan rumah, dan ada juga adat gorontalo pada bulan suci ramadhan yang di meriahkan oleh masyarakat sebelum hari raya tiba yang dinamakan dengan "tumbilatohe".

\section{METODOLOGI PENELITIAN}

Penelitian ini merupakan jenis penelitian pengembangan dengan rancangan penelitian 4-D yang digunakan untuk mengembangkan perangkat pembelajaran inkuiri terbimbing berbasis budaya lokal pada mata pelajaran IPA Fisika dan nilai budaya lokal. Populasi penelitian ini adalah peserta didik SMP Negeri 4 Telaga Gorontalo yang berjumlah 20 orang. Data yang dikumpulkan dalam penelitian ini meliputi 1) Kevalidan perangkat pemebelajaran yang di tinjau dari validasi logis (validasi ahli) dan validasi emperikal, 2) Kepraktisan perangkat pembelajaran yang ditinjau dari observasi keterlaksanaan pembelajaran dan angket peserta didik, 3) Keefektifan perangkat pembelajaran ditinjau dari tes hasil belajar dan observasi aktivitas peserta didik. 


\section{Analisis Keefektifan Perangkat Pembelajaran}

Uji N-Gain

Analisis data penyajian kemampuan menggunakan analisis $N$-Gain. Data hasil tes awal dan tes akhir kemampuan kognitif siswa selanjutnya dihitung peningkatannya yang dinyatakan dalam $\mathrm{N}$-gain (gain ternormalisasi). Untuk memperoleh gain ternormalisasi dari skor pemahaman konsep menggunakan persamaan menurut (Hake, 1999: 34)

$$
\langle\mathrm{g}\rangle=\frac{\% \text { skor post }-\% \text { skore pre }}{100-\% \text { skor pre }}
$$

Keterangan:

$\mathrm{g} \quad=$ Gain (peningkatan kemampuan)

pre $\quad=$ Rata-rata nilai pre test $(\%)$

post $\quad=$ Rata-rata nilai post test $(\%)$

Tabel 1 Kriteria Nilai Uji $N$-gain

\begin{tabular}{ccc}
\hline No & Nilai $\langle\mathrm{g}\rangle$ & Kriteria \\
\hline 1 & $<\mathrm{g}>\geq 0,7$ & Tinggi \\
2 & $0,7>\langle\mathrm{g}\rangle>0,3$ & Sedang \\
3 & $<\mathrm{g}><0,3$ & Rendah \\
\hline
\end{tabular}

Hake, 1999: 34

\section{Analisis Data Observasi Aktivitas Peserta Didik}

Aktivitas peserta didik saat mengikuti proses pembelajaran dapat dianalisis menggunakan rumus:

$\%$ Aktivitas peserta didik $=\frac{\text { Eskor perovenan }}{\text { Eskor maksimum }} \times 100 \%$

Kriterian penilaian observasi aktivitas pesera didik sebagai berikut:

Tabel 2. Skor Kriteria Keefektifan

\begin{aligned} & \hline Skor $(\%) \multicolumn{1}{c}{$ Kriteria Keefektifan } \\ & \hline $81 \%-100 \% \begin{array}{l}\text { sangat baik/sangat menarik/sangat sesuai/sangat efektif/sangat } \\ \text { praktis } \\ \text { baik/ menarik/ sesuai/ efektif/ praktis }\end{array} \\ & 61 \%-80 \% \begin{array}{l}\text { sedang/cukup menarik/cukup sesuai/cukup efektif/cukup } \\ \text { praktis } \\ \text { kurang baik/kurang menarik/kurang sesuai/kurang } \\ \text { efektif/kurang praktis. }\end{array} \\ &$\hline\end{aligned}

Purnomo (2014: 91).

Reliabilitas suatu instrumen yang cukup dipercaya untuk digunakan sebagai alat pengumpul data (Arikunto, 2013:171). Reliabilitas suatu instrumen adalah kekonsistenan instrumen tersebut bila diberikan pada subjek yang sama meskipun oleh orang yang berbeda, 
waktu yang berbeda, atau tempat yang berbeda, maka akan memberikan hasil yang sama atau relatif sama (tidak berbeda secara signifikan. Koefisien reliabilitas tes pada penelitian ini diukur dengan menggunakan rumus alpha Cronbach (Arikunto, 2013:180) yaitu:

$$
r_{11}=\left[\frac{k}{k-1}\right]\left[1-\frac{\left(\Sigma \sigma_{b}^{2}\right)}{\sigma_{t}^{2}}\right]
$$

Keterangan:

$$
\begin{aligned}
r_{11} & : \text { Reliabilitas Instrumen } \\
k \quad & : \text { Banyaknya butir pertanyaan atau banyaknya soal } \\
& : \text { Varian butir } \\
& : \text { Varian total }
\end{aligned}
$$

Untuk mencari varians total dan varians butir menggunakan rumus varians sebagai berikut:

$$
\sigma_{b}^{2}=\frac{\sum X^{2}-\frac{\left(\sum X\right)^{2}}{N}}{N} \text { dan } \sigma_{t}^{2}=\frac{\sum Y^{2}-\frac{\left(\sum Y\right)^{2}}{N}}{N}
$$

Keterangan:

$\sigma_{b}^{2} \quad$ : Varian butir dengan $\mathrm{X}$ : Butir soal

$\sigma_{t}^{2} \quad$ : Varian total dengan Y : Total Butir soal

Nilai $r_{11}$ yang diperoleh dapat diinterpretasikan untuk menentukan reliabilitas instrument dengan menggunakan kriteria pada Tabel 3

Tabel 3. Kriteria Reliabilitas Test

\begin{tabular}{cc}
\hline Koefisien Korelasi & Kriteria \\
\hline $0,80<\mathrm{r} 11 \leq 1,00$ & Sangat tinggi \\
$0,60<\mathrm{r} 11 \leq 0,80$ & Tinggi \\
$0,40<\mathrm{r} 11 \leq 0,60$ & Cukup \\
$0,20<\mathrm{r} 11 \leq 0,40$ & Rendah \\
$0,00<\mathrm{r} 11 \leq 0,20$ & Sangat rendah
\end{tabular}

(Arikunto, 2013:180)

Kriteria pengujian reliabilitas soal tes yaitu setelah didapatkan harga $r_{11}$ tersebut di klasifikasikan dengan besarnya koefisien reliabilitas pada table, jika $r_{11}>r_{\text {tabel }}$ maka item tes yang di uji cobakan reliabel. 
HASIL DAN PEMBAHASAN

Hasil Kevalidan Perangkat Pembelajaran

Tabel 4. Validasi Ahli

\begin{tabular}{|c|c|c|c|c|c|c|}
\hline \multirow{2}{*}{ No } & \multirow{2}{*}{$\begin{array}{l}\text { Perangkat } \\
\text { Pembelajaran }\end{array}$} & \multicolumn{3}{|c|}{ Presentase kelayakan \% } & \multirow{2}{*}{$\begin{array}{c}\text { Rata-rata presentase } \\
\text { kelayakan }(\%)\end{array}$} & \multirow{2}{*}{$\begin{array}{c}\text { Layak/ } \\
\text { tidak layak }\end{array}$} \\
\hline & & V1 & $\mathrm{V} 2$ & V3 & & \\
\hline 1 & Silabus & $75 \%$ & $75 \%$ & $90 \%$ & $80 \%$ & Layak \\
\hline 2 & $\mathrm{RPP}$ & $75 \%$ & $75 \%$ & $92 \%$ & $80,6 \%$ & Layak \\
\hline 3 & Bahan Ajar & $75 \%$ & $100 \%$ & $95 \%$ & $90 \%$ & Layak \\
\hline 4 & LKPD & $75 \%$ & $100 \%$ & $95 \%$ & $90 \%$ & Layak \\
\hline 5 & THB & $75 \%$ & $81 \%$ & $100 \%$ & $85,3 \%$ & Layak \\
\hline
\end{tabular}

\section{Hasil Kepraktisan Perangkat Pembelajaran}

Keterlaksanaan pembelajaran dilihat melalui data pengamatan yang dilakukan oleh 1 pengamat. Berikut hasil data keterlaksanaan perangkat yang dilakukan pada uji coba terbatas dan uji coba lanjutan pada gambar 1.

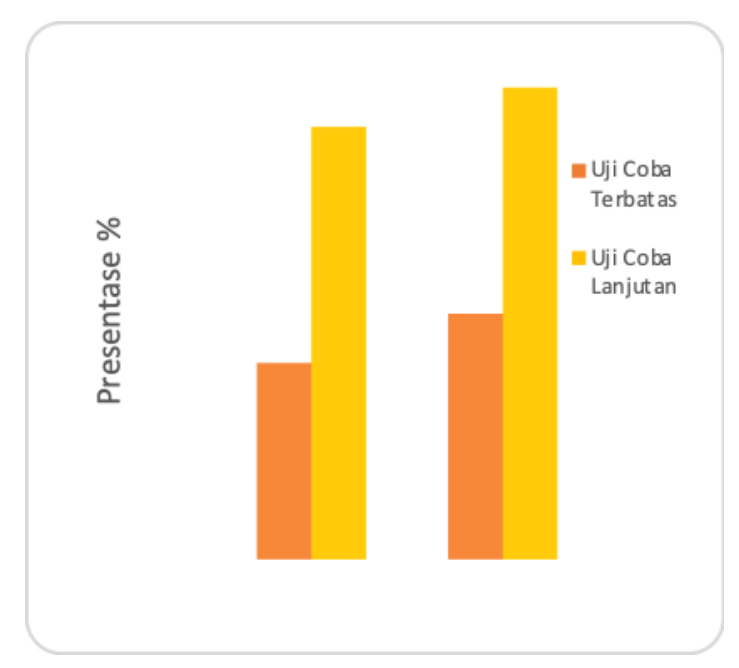

Gambar 1. Keterlaksanaan Pembelajaran

Berdasarkan hasil gambar 1 analisis data dari keterlaksanaan proses pembelajaran terdapat peningkatan hasil dari uji coba terbatas ke uji coba lanjutan dengan menggunakan perangkat pembelajaran berbasis budaya lokal yaitu pada pertemuan 1 dan pertemuan 2 yang telah dilaksanakan dengan nilai rata-rata presentase keterlaksanaan pembelajaran pada uji coba terbatas yaitu $86,25 \%$ dengan kategori masing-masing penilaian pengamat adalah Baik. Sedangkan pada uji coba lanjutan nilai rata-rata keterlaksanaan pembelajaran yaitu $98 \%$. Ini berarti bahwa perangkat pembelajaran yang dikembangkan dapat digunakan untuk mengelola 
pembelajaran (keterlaksanaan pembelajaran tercapai) serta memiliki peningkatan rentang (86,25\%-98\%) dari proses pembelajaran yang dilakukan. Untuk setiap pertemuan menunjukkan presentase masing-masing $97 \%$ dan $99 \%$ yang termasuk dalam kriteria sangat baik.

\section{Respon Peserta Didik}

Respon peserta didik dilihat melalui observasi angket peserta didik yang mengisi indikator terhadap pengembangan perangkat pembelajaran berbasis budaya lokal. Berikut hasil data angket peserta didik yang diisi pada uji coba terbatas dan uji coba lanjutan.

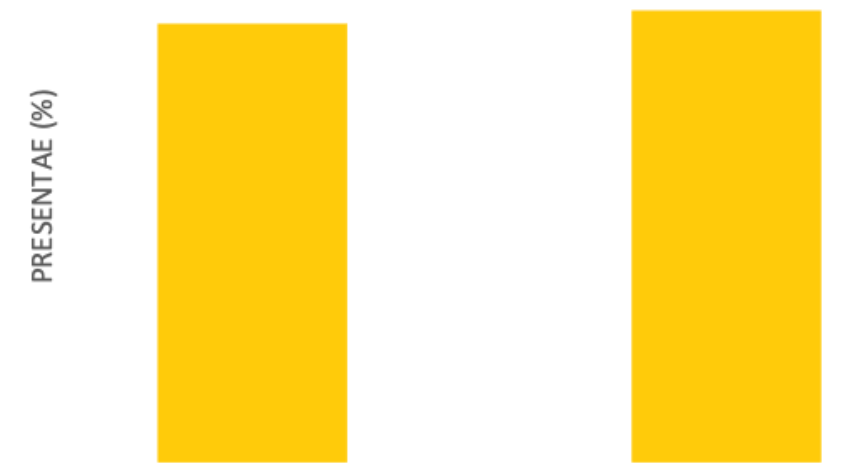

Gambar 2. Angket Respon Peserta Didik

Berdasarkan hasil yang ditampilkan pada gambar 2 analisis angket peserta didik terhadap perangkat pembelajaran yang peneliti kembangkan pada materi energi dalam sistem kehidupan menunjukkan bahwa peserta didik merespon secara baik tentang perangkat pembelajaran yang peneliti kembangkan. Dan terdapat peningkatan respon peserta didik dari uji coba terbatas ke uji coba lanjutan karena proses pembelajaran di uji coba lanjutan lebih menunjukkan perubahan terhadap proses pembelajaran. Dalam hasil angket respon peserta didik yaitu (89,64\%-92\%). Hal ini menunjukan bahwa hasil angket peserta didik memenuhi kriteria kepraktisan.

\section{Hasil Keefektifan Perangkat Pembelajaran}

\section{Aktivitas Peserta Didik}

Aktivitas Peserta didik diamati oleh pengamat sebanyak dua kali pertemuan selama proses pembelajaran berlangsung. Dengan menggunakan lembar observasi aktivitas peserta didik yang terdiri dari 10 Indikator. Adapun indikator yang diamati mengamati demonstrasi terkait permasalahan yang diangkat, mengajukan pertanyaan, melakukan percobaan, menganalisis data, mempresentasikan hasil percobaan, menanggapi hasil diskusi, memberikan pertanyaan sesuai masalah, menyimak penjelasan guru dan menyimpulkan materi. Data hasil pengamatan diperoleh berdasarkan skor yang diberiakan oleh pengamat dengan rentang 1-3 sesuai dengan jumlah deskriptor yang diamati. Berikut adalah data analisis aktivitas peserta 
didik.

Berikut hasil data aktivitas peserta didik yang dilakukan pada uji coba terbatas dan uji coba lanjutan.

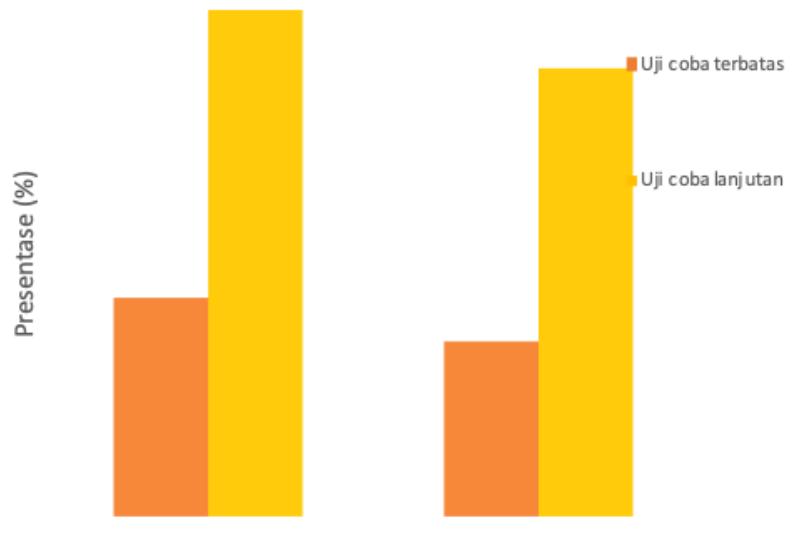

Gambar 3. Aktivitas Peserta Didik

Berdasarkan gambar 3 dapat diketahui bahwa hasil analisis aktivitas peserta didik terdapat peningkatan hasil dari uji coba terbatas ke uji coba lanjutan dalam pertemuan 1 dan pertemuan 2. Uji coba terbatas dari reponden 20 peserta didik yang di amati oleh 2 pengamat dalam pertemuan 1 yaitu $81 \%$ dan pertemuan 2 yaitu $80 \%$. Pada uji coba lanjutan dengan responden 20 peserta didik dalam pertemuan 1 yaitu 87,58\% dan pertemuan 2 yaitu 86,92\%. Itu karena aktivitas peserta didik pada pertemuan 2 sudah tidak terlalu menggunakan percobaan hanya saja peserta didik lebih ke arah pendiskusian terhadap materi perpindahan energi. Pada hasil uji coba lanjutan pada kelas VII.2 mendapatkan peningkatan aktivitas peserta didik dengan proses pembelajaran berbasis budaya lokal yang lebih menarik perhatian peserta didik dalam melakukan percobaan dan menimbulkan rasa ingin tahu terhadap permasalahan yang diberikan guru. Peserta didik lebih aktif dan mulai banyak mengajukan pertanyaan dalam menyelesaikan percobaan yang dilakukan dan lebih aktif dalam komunikasi presentasi terhadap teman-teman sekelas.

\section{Tes Hasil Belajar}

Tes Hasil Belajar peserta didik diberikan kepada peserta didik VII.2 yang berjumlah 20 orang, tes berupa uraian 7 nomor. Secara keseluruhan nilai rata-rata $N$-Gain Uji terbatas dan N-Gain Uji Lanjutan.

Berdasarkan gambar 4 hasil grafik analisis diatas dapat dilihat pada uji coba lanjutan mengalami peningkatan dari uji coba terbatas. Itu dilihat dari hasil uji coba terbatas terdapat nilai n-gain $0,76 \%$ dan pada uji coba lanjutan yaitu $0,86 \%$ peningkatan nilai rata-rata n-gain terhadap uji coba terbatas dan uji coba lanjutan yaitu $0,81 \% .0,8(<\mathrm{g}>\geq 0,7)$ termasuk kriteria 
tinggi. Pada tes hasil belajar terdapat 7 nomor butir soal yang valid dan reliabilitas. Adapun hasil olahan data validasi setiap butir soal pada tabel 5 .

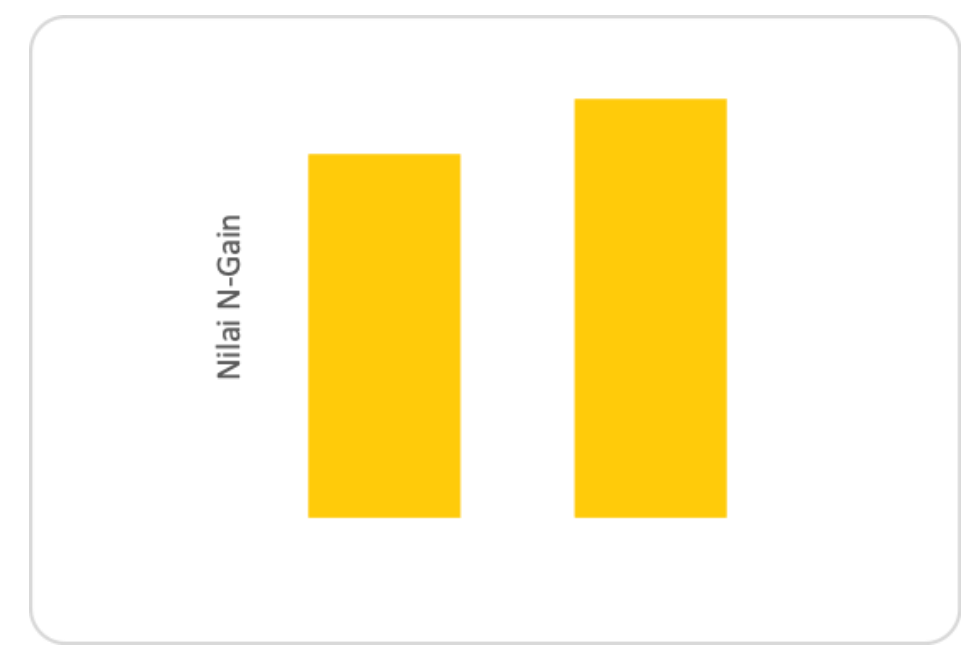

Grafik 4. Nilai N-gain Uji Terbatas dan Uji Lanjutan

Tabel 5. Uji Validitas Tes

\begin{tabular}{lll}
\hline No butir soal & \multicolumn{1}{c}{ Nilai } & \multicolumn{1}{c}{ Kriteria } \\
\hline 1 & 0,47 & Valid \\
2 & 0,54 & Valid \\
3 & 0,67 & Valid \\
4 & 0,58 & Valid \\
5 & 0,54 & Valid \\
6 & 0,54 & Valid \\
7 & 0,46 & Valid \\
\hline
\end{tabular}

Berdasarkan Tabel 5 hasil validasi item pada setiap indikator yaitu $r$ hitung $>r$ tabel yaitu 0,44. Sehingga memenuhi kriteria Valid.

\section{Pembahasan}

Penelitian ini menggunakan model 4-D yang terdiri dari beberaa tahapan yakni pendefinisian (define), perancangan (design), pengembangan (develop) dan penyebaran (dessiminate). Namun pada penelitian ini hanya dilakukan sampai tahap pengembangan (develop). Sebelum dilakukan tahap pengembangan, terlebih dahulu dilakukan tahap perancangan (design). Pada tahap perancangan diperoleh rancangan perangkat pembelajaran yang dibuat sendiri oleh peneliti yang terdiri dari Silabus, Rencana Pelaksanaan Pembelajaran (RPP), Bahan Ajar, Lembar Kerja Peserta Didik (LKPD), Media Pembelajaran dan Tes Hasil Belajar (THB). Pada tahap ini dilakukan pemilihan media untuk membelajarkan peserta didik pada materi energi dalam sistem kehidupan menggunakan alat berbasis budaya lokal dalam kehidupan sehari-hari. Alat-alat budaya lokal seperti lampu botol yang digunakan dalam 
tradisi tumbilatohe Gorontalo. Budaya ini akan dikaji konsep-konsep fisika yang terdapat dalam budaya tersebut yaitu konsep energi. Selanjutnya survei lapangan untuk mengumpulkan data berkenaan dengan perencanaan dan pelaksanaan pembelajaran di sekolah. Survei lapangan dilakukan di SMP Negeri 4 Telaga. Kemudian menyusun perangkat pembelajaran yang berbasis budaya lokal (draf 1).

Pada tahap pengembangan dilakukan melalui beberapa langkah yaitu validasi ahli yang dilakukan oleh 3 orang validator, revisi perangkat pembelajaran berdasarkan masukan dari validator, uji coba terbatas dan uji coba lanjutan perangkat pembelajaran. Untuk tahap pengembangan, perangkat pembelajaran yang terdiri dari Silabus, RPP, Bahan Ajar, LKPD, Media pembelajaran dan THB berbasis budaya lokal (draft 2) yang disusun oleh peneliti di analisis dan dilakukan uji terbatas pada 20 peserta didik kelas VII.1 di SMP Negeri 4 Telaga

Berdasarkan pembelajaran yang dilakukan di kelas VII.1, ada beberapa hal yang perlu dilakukan perbaikan yaitu pada tes hasil belajar soal nomor 2 jelaskan diubah menjadi identifikasilah, soal nomor 5 yang terlalu pendek di ubah dengan soal cerita yang menggunakan kata identifikasilah. Selain itu waktu yang diperlukan untuk pertemuan pertama menggunakan pembelajaran berbasis budaya lokal tidak cukup. Waktu pembelajaran ditambah satu jam dari waktu sebelumya. Setelah uji coba terbatas, dilakukan revisi dan menghasilkan perangkat draft, selanjutnya dilakukan uji coba lanjutan pada siswa kelas VII.2 yang berjumlah 20 orang

Berdasarkan analisis perangkat pembelajaran data analisis hasil uji coba pada pertemuan 1, dan pertemuan 2 mencakup: (1) hasil analisis data keterlaksanaan pemebelajaran, (2) hasil analisisis aktivitas peserta didik, (3) hasil analisis data angket guru dan peserta didik dan (4) hasil analisis data tes hasil belajar peserta didik.

\section{KESIMPULAN}

Perangkat pembelajaran yang dihasilkan berupa silabus, rencana pelaksanaan pembelajaran (RPP), bahan ajar, lembar kegiatan peserta didik (LKPD), dan tes hasil belajar telah memenuhi kualitas Valid, Praktis, dan Efektif. Yang dapat diuraikan sebagai berikut:

a. Kevalidan perangkat pembelajaran diperoleh dari hasil validasi ahli terhadap pembelajaran yang dikembangkan. Hasil validasi yang diperoleh menunjukan bahwa perangkat pembelajaran telah memenuhi kriteria valid. Hasil analisis validitas item dan reabilitas untuk instrumen penilaian menunjukan bahwa $r_{\text {hitung }}>r_{\text {tabel }}\left(r_{\text {tabel }}=0,444\right)$ sehingga perangkat pembelajaran yang dikembangkan telah memenuhi kategori Valid

b. Kepraktisan perangkat pembelajaran diperoleh melalui hasil peserta didik terhadap pembelajaran dan keterlaksanaan pembelajaran. Hasil angket peserta didik memperoleh 
respon positif dan hasil pengamatan keterlaksanaan pembelajaran sebesar $98 \%$ dengan kriteria sangat baik. Sehingga perangkat pembelajaran yang dikembangkan memenuhi kriteria Praktis

c. Kefektifan perangkan pembelajaran diperoleh dengan melalui hasil pengukuran tes hasil belajar dan aktivitas peserta didik. Hasil tes hasil belajar menunjukan sebesar $88,6 \%$ yang menunjukan kriteria baik dan aktifitas peserta didik sebesar 86,92\% dengan kriteria sangat baik. Dengan demikian perangkat pembelajaran telah memenuhi kategori efektif.

\section{REFERENSI}

Abdullah, M. 2006. Diktat Kuliah Fisika Dasar II Tahap Persiapan Bersama ITB Bandung: FMIPA ITB

Ahmad Susanto. 2013. Teori Belajar dan Pembelajaran di Sekolah Dasar. Jakarta: Kencana Prenadamedia Group

Arikunto, S. (2013). Prosedur Penelitian: Suatu Pendekatan Praktik. Jakarta: Rineka Cipta.

Badan Standar Nasional Pendidikan. 2006. Peraturan Menteri Pendidikan Nomor 22,23, dan 24 Tahun 2006 tentang Standar Isi dan Standar Kompetensi Lulusan Pendidikan dasar dan menengah. Jakarta: BNSP

Farida N.K dan Prihatin S. 2015. Pengembangan Bahan Ajar IPA Berbasis Kearifan Lokal. Dalam Jurnal Pendidikan IPA Universitas Kanjuruhan Malang.

Panjaitan Ade, dkk. 2014. Pendidikan Multikultural. Jakarta: Pustaka

Purnomo, B. B. 2014. Dasar-dasar urologi. Edisi Ketiga. Malang: penerbit CV Sagung seto

Supardi. 2015. Penilaian autentik pembelajaran afektif, kognitif, dan psikomotor. Jakarta: PT Rajagrafindo Persada. 